\title{
Synthesis of a heulandite-type zeolite by hydrothermal conversion of zeolite P1
}

\author{
Shervin Khodabandeh and Mark E. Davis* \\ Department of Chemical Engineering, California Institute of Technology, Pasadena, CA 91125, USA
}

\section{A synthetic analogue of the zeolite heulandite is synthesized by hydrothermal treatment of zeolite $\mathrm{P} 1$ with solutions containing $\mathrm{CaCl}_{2}$ and $\mathrm{NaOH}$.}

Heulandite-type zeolites (heulandite and clinoptilolite) are the most abundant natural zeolites; in spite of this, their synthesis in the laboratory has been extremely difficult. A natural calciumdominant zeolite, heulandite possesses a two-dimensional pore structure consisting of intersecting channels in distinct crystallographic directions bounded by eight and ten tetrahedral atoms. ${ }^{1}$ Heulandite zeolites have $\mathrm{Si} / \mathrm{Al}$ ratios between 2.8 and 4. Clinoptilolite is a heulandite-type zeolite that has an $\mathrm{Si} / \mathrm{Al}$ ratio $>4$, and a sodium and potassium content such that $(\mathrm{Na}+\mathrm{K})>$ $\mathrm{Ca}^{2}$ Although heulandite and clinoptilolite have the same framework topology, the natural conditions under which they are formed, as well as their physical properties are markedly different. This distinction between heulandite and clinoptilolite is similar to the distinction made between faujasite-type zeolites $\mathrm{X}$ and $\mathrm{Y}$.

Natural heulandite-type zeolites have found use in ionexchange and adsorption applications. However, impurities such as iron that are commonly found in natural samples make the application of heulandite as a catalyst very limited. A potential catalytic application of a pure heulandite is the isomerization of but-1-ene to 2-methylpropene as suggested by the recent work of Woo et al. ${ }^{3}$ To date, synthesis of heulanditetype zeolites has proven exceedingly difficult. There are two reported synthetic routes to heulandite. One of these requires extreme conditions of pressure and temperature $(p>1000 \mathrm{~atm}$, $\left.T>250^{\circ} \mathrm{C}\right)^{4}$ and the other involves synthesis times of 40 to 80 d. ${ }^{5}$ Additionally, several preparations of clinoptilolite are also given in the literature. ${ }^{6-11}$

Here we present a synthetic route to heulandite starting from zeolite P1. To the best of our knowledge, this is the first synthesis of a zeolite with the heulandite structure that is accomplished through the transformation of another zeolite. It is also the first synthesis of heulandite at 'typical' zeolite synthesis conditions.

Heulandite can be obtained by means of hydrothermal treatment of specifically prepared zeolite P1 with aqueous solutions containing $\mathrm{Ca}^{2+}$ and $\mathrm{Na}^{+}$ions using heulandite or clinoptilolite seeds at temperatures between 200 and $240^{\circ} \mathrm{C}$. The zeolite P1 used in this transformation must have a minimum $\mathrm{Si} / \mathrm{Al}$ ratio of 3.0. Two starting materials were used for the synthesis of zeolite $\mathrm{P} 1$ as described below.

Zeolite P1 with an Si/Al ratio of 3.0-3.2 can be synthesized by treatment of perlite glass (PA-1000, Johns-Manville) with an aqueous solution of $\mathrm{Na}_{2} \mathrm{CO}_{3}-\mathrm{NaOH}$ at temperatures ranging from 110 to $240^{\circ} \mathrm{C}$ and with synthesis times of $2 \mathrm{~h}$ to $11 \mathrm{~d}$. Although zeolite $\mathrm{P} 1$ is obtained from perlite over a range of solution concentrations, temperatures and reaction times, it is observed that reactions at lower $\mathrm{pHs}$, lower temperatures and longer times result in products with higher crystallinity. A typical procedure is as follows. Ten $\mathrm{ml}$ of a solution of 0.8 mol dm ${ }^{-3} \mathrm{Na}_{2} \mathrm{CO}_{3}(\mathrm{pH}=11.4)$ was added to $0.50 \mathrm{~g}$ of perlite (PA-1000 from Johns-Manville) in a Teflon-lined $23 \mathrm{ml}$ autoclave and heated for 11 days at $120^{\circ} \mathrm{C}$. The solid was then filtered and washed and is identified as Na-P1 with an $\mathrm{Si} / \mathrm{Al}$ ratio of 3.2 (obtained from ${ }^{29} \mathrm{Si}$ NMR spectroscopy and elemental analysis). The powder X-ray diffraction pattern of this solid is shown in Fig. 1(a).

Since perlite glass is a natural material, it contains impurities similar to those found in natural heulandite. Therefore, we developed a synthesis route to heulandite that utilized pure starting reagents. Zeolite $\mathrm{P} 1$ was prepared from an amorphous aluminosilicate gel having the composition $\mathrm{Al}_{2} \mathrm{O}_{3}: 9.4$ $\mathrm{SiO}_{2}: 3.7 \mathrm{Na}_{2} \mathrm{O}: x \mathrm{H}_{2} \mathrm{O}$ as follows. Two grams of sodium aluminate (from $\mathrm{EM}$ ) were dissolved in $60 \mathrm{ml}$ of distilled water and $4 \mathrm{~g}$ of a $50 \% \mathrm{~m} / \mathrm{m}$ solution of $\mathrm{NaOH}$ were added to this solution. The solution was stirred while $5.20 \mathrm{~g}$ of Cab-O-Sil (grade M5) were slowly added. The resulting gel was stirred at room temp. for $48 \mathrm{~h}$ after which stirring was stopped and the gel allowed to dry at room temp. for one week. Zeolite P1 was obtained by heating a mixture of $0.5 \mathrm{~g}$ of this solid and $10 \mathrm{ml}$ of $0.4 \mathrm{~mol} \mathrm{dm}-3 \mathrm{Na}_{2} \mathrm{CO}_{3}$ at $150{ }^{\circ} \mathrm{C}$ for $5 \mathrm{~d}$ in a $23 \mathrm{ml}$ Teflon-lined autoclave. The XRD pattern of this solid is shown in Fig. 1(b). Elemental analysis and ${ }^{29} \mathrm{Si}$ NMR spectroscopy performed on this material yielded an $\mathrm{Si} / \mathrm{Al}$ ratio of 3.0. A variety of experimental conditions (e.g. $\mathrm{pH}$, temperature and crystallization time) allow for the synthesis of zeolite P1 from this gel. However, few of these conditions yield $\mathrm{Pl}$ with $\mathrm{Si} / \mathrm{Al}>3$; lower $\mathrm{Si} / \mathrm{Al}$ ratios and typical impurities of analcime and quartz are obtained at higher pHs, longer crystallization times and higher temperatures.

Zeolite P1 prepared as above can be transformed to heulandite in the presence of aqueous $\mathrm{Ca}^{2+}$ and heulandite or clinoptilolite seeds within $16 \mathrm{~d}$ at $240^{\circ} \mathrm{C}$ and autogenous pressure. A typical procedure is as follows. One gram of $\mathrm{Pl}$ (synthesized as above) was ion-exchanged at $80^{\circ} \mathrm{C}$ overnight by contact with $100 \mathrm{ml}$ of a $0.50 \mathrm{~mol} \mathrm{dm}^{-3}$ solution of $\mathrm{CaCl}_{2}$ in order to obtain Ca-P1. To $10 \mathrm{ml}$ of a solution of $0.050 \mathrm{~mol} \mathrm{dm}^{-3}$ $\mathrm{CaCl}_{2}$ and $0.0012 \mathrm{~mol} \mathrm{dm}-3 \mathrm{NaOH}(\mathrm{pH}=11.05)$ was added $0.20 \mathrm{~g}$ of $\mathrm{Ca}-\mathrm{Pl}$ and $0.010 \mathrm{~g}$ (5\% by mass) of Ca-exchanged natural clinoptilolite as seed. The mixture was heated in a Teflon-lined autoclave at $240^{\circ} \mathrm{C}$ and autogenous pressure for $16 \mathrm{~d}$. The solid was then washed and filtered and identified as heulandite. The X-ray powder diffraction pattern of this solid

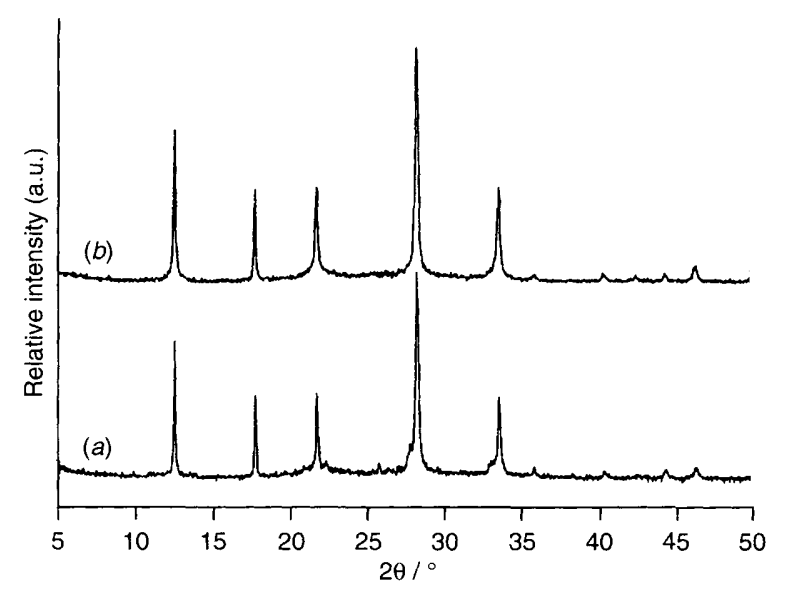

Fig. $1 \mathrm{X}$-Ray powder diffraction patterns of zeolite P1 synthesized from (a) perlite and $(b)$ an aluminosilicate gel 
after 8 and $16 \mathrm{~d}$ is shown in Fig. 2. Fig. 3 shows the ${ }^{29} \mathrm{Si} \mathrm{NMR}$ spectra of the starting P1 phase and the synthetic heulandite. Synthetic heulandite has an $\mathrm{Si} / \mathrm{Al}$ ratio of 4.0 as determined by ${ }^{29} \mathrm{Si}$ NMR spectroscopy and elemental analysis and a water content of $13.5 \%$ by mass. Synthetic heulandite is indexed to a monoclinic unit cell with $a=17.73, b=17.97, c=7.43 \AA$ and $\beta=116^{\circ} 21^{\prime}$

Conversion of Ca-P1 to heulandite can be accomplished with some variations in the $\mathrm{pH}$ and the calcium and sodium content of the solution, but will not occur if calcium is not present in the solution. In fact, even with $20 \%$ seeds of heulandite, if the ratio

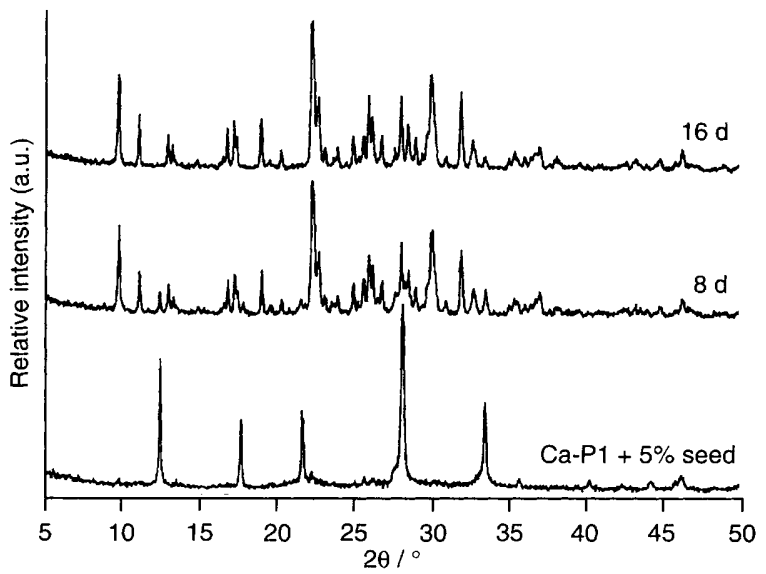

Fig. $2 \mathrm{X}$-Ray powder diffraction patterns showing the transformation of $\mathrm{Ca}-\mathrm{P} 1$ to heulandite over $16 \mathrm{~d}$

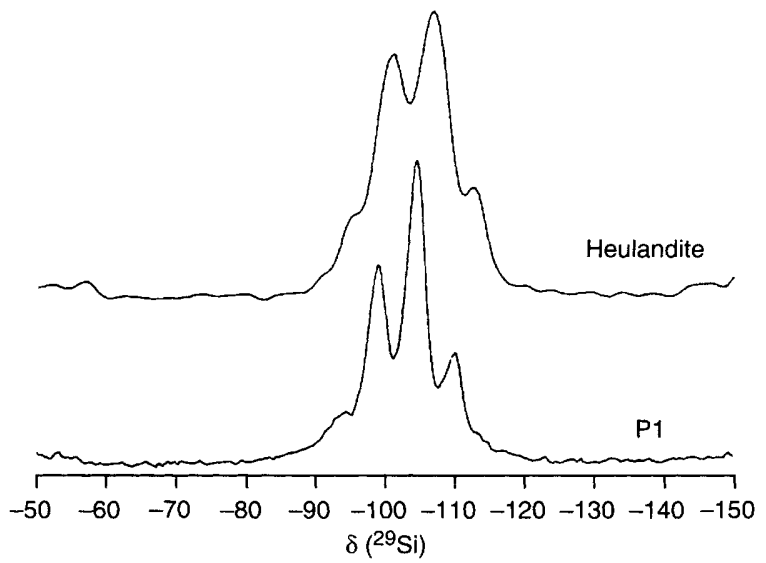

Fig. $3{ }^{29}$ Si NMR spectra of zeolite P1 and synthetic heulandite of $\mathrm{Na}^{+} / \mathrm{Ca}^{2+}$ in the complete reaction mixture is not $<0.1$, other phases such as analcime and mordenite will be formed and no heulandite will be obtained. The rate of conversion of $\mathrm{Ca}-\mathrm{P} 1$ to heulandite does not depend on the concentration of $\mathrm{Ca}^{2+}$ in the solution and remains essentially the same as the concentration of $\mathrm{Ca}^{2+}$ is altered from 0.050 to $0.50 \mathrm{~mol} \mathrm{dm}^{-3}$ at an initial $\mathrm{pH}$ of 11.0. Na-P1 can also be transformed to heulandite under similar conditions provided that the $\mathrm{Na}^{+} / \mathrm{Ca}^{2+}$ ratio in the complete reaction mixture is $<0.1$. Contrary to $\mathrm{Ca}-\mathrm{P} 1$, the rate of conversion of Na-P1 to heulandite increases with increasing concentration of $\mathrm{Ca}^{2+}$ in the solution phase. When the concentration of $\mathrm{Ca}^{2+}$ reaches $0.50 \mathrm{~mol} \mathrm{dm}-3$, the rate of conversion to heulandite for both $\mathrm{Na}-\mathrm{P} 1$ and $\mathrm{Ca}-\mathrm{P} 1$ is essentially the same. Thus, exchange of $\mathrm{Ca}^{2+}$ for $\mathrm{Na}^{+}$in the $\mathrm{Na}$ $\mathrm{P} 1$ must take place before the conversion of $\mathrm{Ca}-\mathrm{P} 1$ to heulandite.

Thus far, we have not been able to convert zeolite P1 to heulandite in the absence of heulandite or clinoptilolite seeds although the amount of seeds can be as small as $3 \%$. At $200^{\circ} \mathrm{C}$, $\mathrm{P} 1$ can still be transformed to heulandite but at a slower rate ( $\mathrm{ca}$. $24 \mathrm{~d}$ for complete conversion). Attempts to convert zeolites $\mathrm{X}$ $(\mathrm{Si} / \mathrm{Al}=1.2), \mathrm{Y}(\mathrm{Si} / \mathrm{Al}=2.4$ to 3.5$)$, as well as $\mathrm{P} 1(\mathrm{Si} / \mathrm{Al}=1.0$ to 2.9) to heulandite were not successful even when as much as $20 \%$ seeds were used. Furthermore, the aluminosilicate gel from which P1 was synthesized is not converted to heulandite because the high sodium content does not allow for an $\mathrm{Na}^{+} / \mathrm{Ca}^{2+}$ ratio of $<0.1$. It is possible to transform perlite glass to heulandite but this procedure requires synthesis times in excess of several $(8-10)$ weeks. Thus, the P1 material with $\mathrm{Si} / \mathrm{Al}>3$ appears to be particularly suitable for conversion to heulandite.

The authors thank Akzo Nobel for financial support.

\section{References}

1 S. M. Meier and D. H. Olson, Atlas of Zeolite Structure Types, Butterworths, London, 1987.

2 G. Gottardi and E. Galli, Natural Zeolites, Springer-Verlag, Heidelberg, 1985.

3 H. C. Woo, K. H. Lee and J. S. Lee, Appl. Catal. A, 1996, 134, 147

4 M. Koizumi and R. Roy, J. Geol., 1960, 68, 41.

5 U. Wirsching, Clays Clay Mineral., 1981, 29, 171

6 L. L. Ames, Jr., Am. Mineral., 1965, 48, 1374.

7 D. B. Hawkins, Mater. Res. Bull., 1967, $2,951$.

8 Y. Goto, Am. Mineral., 1977, 62, 330.

9 D. B. Hawkins, R. A. Sheppard and J. A. Gude, in Natural Zeolites: Occurrence, Properties, Use, ed. L. B. Sand and F. A. Mumpton, Pergamon, Oxford, 1978, p. 337.

10 C. H. Chi and L. B. Sand, Nature, 1983, 304, 255.

11 S. Satokawa and K. Itabashi, Eur. Pat. Appl., 681991, 1995.

Received, 23rd January 1996; Com. 6/00512H 